\section{OPEN JOURNAL SYSTEMS}

ISSN:2237-2202
Available on line at Directory of Open Access Journals

Journal of Hyperspectral Remote Sensing v.7, n.5 (2017) 272-283

www.periodicos.ufpe.br/revistas/jhrs
Journal of Hyperspectral Remote Sensing

\title{
Multitemporal analysis of vegetation indices for the superior region of the Moxotó River hydrographic basin
}

\author{
Ulisses A. Bezerra*, Leidjane M. M. de Oliveira**, Antônio C. de S. Leite***, Débora N. O. de Almeida****, Ana \\ Lúcia B. Candeias*****, João R. Tavares Junior****** \\ * Graduated in Environmental Engineering, Postgraduate in Geodetic Sciences and Geoinformation Technologies, Federal \\ University of Pernambuco (UFPE), Recife-PE. E-mail: ulisses.alencar17@gmail.com (corresponding author) \\ **Adjunct Professor; Federal University of Pernambuco (UFPE), Recife-PE. E-mail: leidjaneoliveira @ hotmail.com \\ ${ }^{* * *}$ Graduated in Geoprocessing Technology, Postgraduate in Geodetic Sciences and Geoinformation Technologies, Federal \\ University of Pernambuco (UFPE), Recife-PE. E-mail: antoniocelsoleite@gmail.com \\ ${ }^{* * * * *}$ Graduated in Cartographic Engineering; Federal University of Pernambuco (UFPE), Recife-PE. E-mail: \\ debora.nathalia21@gmail.com \\ ${ }^{* * * * * *}$ Associate Professor III; Federal University of Pernambuco (UFPE), Recife-PE. analucia@ufpe.br \\ Adjunct Professor II; Federal University of Pernambuco (UFPE), Recife-PE. E-mail: rodriguesjoao380@ gmail.com
}

Received 19 August 2017; accepted 28 September 2017

\begin{abstract}
The semi-arid region of Northeastern part of Brazil is under changes pressures driven by human activities or climate changes. This study aims to assess the vegetation coverage in two periods, before the transposition of the São Francisco River-East axis, and after your implementation, in the Moxotó River basin using remote sensing techniques to determine vegetation indices, and investigate the behavior of vegetation in the catchment area. The Normalized Difference Vegetation Index (NDVI) and the Soil Adjusted Vegetation Index (SAVI). TM-Landsat5 image of 13/01/2009, and OLI-Landsat8 image of 04/02/2017 are used here. Radiometric calibration steps, reflectance are developed to generate thematic maps of NDVI and SAVI. The NDVI showed average values for 2009 and 2017 like 0,256 and 0,264, respectively, setting a growth of vegetation cover and photosynthetic activity. The SAVI had an average of 0,147 and 0,155 to years of 2009 and 2017, respectively. Differences were found between vegetable toppings determined by NDVI and by SAVI. The exposed soil class had greater expression when observed in the thematic maps of NDVI, once the SAVI, has the precept to reduce the brightness of the ground, and this index had a higher representation in the sparse vegetation.

Keywords: remote sensing, semiarid, NDVI, SAVI
\end{abstract}

\section{Introduction}

Water resources are at the heart of sustainable development and the diversity of services promoted by these contribute to poverty reduction, economic growth and environmental sustainability (UNESCO, 2015).

Historically, much of the Brazilian Northeast region live with long and frequent periods of drought. The semi-arid region, which covers most of the northeastern semi-arid and agreste region, is in this situation, resulting in a large water stress. On the other hand, in semi-arid zones, high evapotranspiration flows occur, and accentuating the water deficits in the periods without rainfall (Gheyi et al., 2012; Silva et al., 2014).
According Brito (2013), water flows in rivers and aquifers, as well as the volumes stored in them, either naturally or artificially, constitute mobile water reserves as they can be used outside the places where the rains have fallen origin, through the construction of "artificial rivers" (channels of transposition). In this context, a transposition of water can have multiple targets such as agricultural and industrial activities or adduction for urban and / or rural supply.

The basic objective in the arid and semi-arid regions is water security of which is to raise the level of water supply for multiple uses, in areas that are at the limit between supply and demand. The idea of the transposition of waters and basins provide integration 
hydrological regions devoid, with waters from regions with higher possibilities of supply and thus resolve and/or minimize the problem of shortages in the region (Brito, 2013).

A river basin can undergo environmental changes due to many factors, as well as anthropic perturbations such as changes in land use and occupation, urban development, forest fragmentation, among others (Constantini, 2012). According Melo (2011), the Moxotó River basin, has a strategic location in the northeastern semi-arid region, having featured for the relevant contribution to the public water supply in the region, in addition to presenting great economic, social and cultural importance.

According to Oliveira et al. (2013), remote sensing (RS) has reached high utilization rates, since quality and agility represent an effective and economically viable way to collect data, aiding in monitoring and being able to model nature phenomena. The RS has become an extraordinary technology for obtaining climatic and environmental information, because it allows the summary or detailed analysis of the object of study, per to introduce, speed of data processing, practicality and low cost.

Antunes (2014) argued that the classical conceptualization to define RS refers to the use of objects or phenomena of the earth's surface by means of sensors, without direct contact with them. This information is collected through electromagnetic radiation, in which it is one of the main elements for the understanding of remote sensing, along with the source, the sensor and the target.

Among its instruments, RS allows the observation of vegetation spectral parameters and biophysical parameters of the landscape (Chagas et al., 2008), providing analyzes of changes and alterations in natural features through the modification of spectral behavior, evidenced by the indices of vegetation.

According to Ponzoni et al. (2012), several vegetation indices have been presented with the objective of investigating the spectral properties of the vegetation, as well as water body, specifically in the visible and near infrared regions. Among the many indices used to determine the vegetation cover, two of them have been widely used: NDVI and SAVI.

The NDVI (Normalized Difference of Vegetation Index), elaborate by Rouse et al. (1973), is an important element for the study of climate change, using vegetation as a calculation index. In addition, assigning to the studied area a certain value that will depend on the state of this vegetation, constituting an important strategy for the monitoring of the changes naturals or anthropogenic in the environment (Lopes et al., 2010).

Radiation arriving at the surface of the Earth (global radiation), upon reaching the vegetable surface, interacts with it, and derives in three fractions. A part of this radiation is absorbed by the pigments contained in the leaf and participates in the synthesis of rich compounds in energy. Another part of this radiation is reflected by the leaves, a phenomenon called reflection, range that applies, the NDVI. And the last stage, the transmission process through the layers of leaves that make up the treetops and leaves of plants (Lima et al., 2013).

According to Ponzoni et al. (2012), the leaves have a low reflectance in the region of the visible, fact that is explained by the absorption of the radiation under the action of the photosynthetic pigments, while inside the leaves, a high reflectance occurs in the region of the near infrared, which is caused by scattering (reflectance and transmittance).

Looking for to minimize the effects of background soil in the sign of the vegetation, Huete (1988), proposed a vegetation index adjusted for soil, the SAVI (Soil Adjusted Vegetation Index), incorporating the L factor, which corresponds to a solo tuning, in the denominator of the equation NDVI (Marcussi et al., 2010). According to the same author, this index is recommended for application in arid and semi-arid environments.

In this context, this paper objective, aims to analyze the vegetation cover through the NDVI and SAVI in two periods, before the transposition- east axis of the São Francisco River, and after your implementation, in the Moxotó River basin, in the municipalities of Custódia and Sertânia, both located in the Sertão the Pernambuco.

\section{Materials and methods}

\subsection{Characterization of the study area}

The areas selected for this study are the municipalities of Custódia and Sertânia, located in the upper area of the hydrographic basin of the Moxotó river (Figure 1). This basin contemplates an area of $9,752.71 \mathrm{~km}^{2}$, with $90 \%$ in the territories in Pernambuco and adding the rest of its area to the state of Alagoas. The hydrographic basin is located between the coordinates $07^{\circ} 52 ' 21$ "and $099^{\circ} 19^{\prime} 03^{\prime \prime}$ South latitude, and between the coordinates $36^{\circ} 57^{\prime} 49$ "and $38^{\circ} 14 ' 41^{\prime \prime}$ West longitude, and is inserted in the UP8 Water Planning Unit (APAC, 2017).

According to the Agência Pernambucana de Águas e Clima - APAC (2017), the main tributary of 
the hydrographic basin of the referent study, the Moxotó river is born in the municipality of Sertânia, near the border between the states of Pernambuco and Paraíba. São Francisco river has an extension of about $226 \mathrm{~km}$. Because of its characteristic of pass by more than one state, it is a watercourse under the control of the Union. It has an intermittent regime with several reservoirs along its course.

The municipalities of Custódia and Sertânia account for $88.6 \%$ and $100 \%$ of their area within the hydrographic basin of the Moxoto river, respectively. They have semi-arid climate with an average temperature of $25^{\circ} \mathrm{C}$ and annual rainfall less than 700 $\mathrm{mm}$. The predominant vegetation is the hyperxerophilic caatinga. The rainy season is comprised from March to
July, during the rest of the year, drought predominates (Melo, 2011; Gomes et al., 2016).

Rainfall data obtained through the APAC website were used for understand the rainfall indices in the study area. Monthly precipitation data were collected from January to May, from the years referring to Landsat images (2009 and 2017), used in this research according to the graphic (Figure 2).

It is observed that the months of January to May of the year 2009 totaled $934 \mathrm{~mm}$ and $591.9 \mathrm{~mm}$, in the pluviometric stations of the municipalities of Custódia and Sertânia respectively, and in 2017 totaled $420.5 \mathrm{~mm}$ and $247.6 \mathrm{~mm}$, in the same municipalities and in the same period of months.

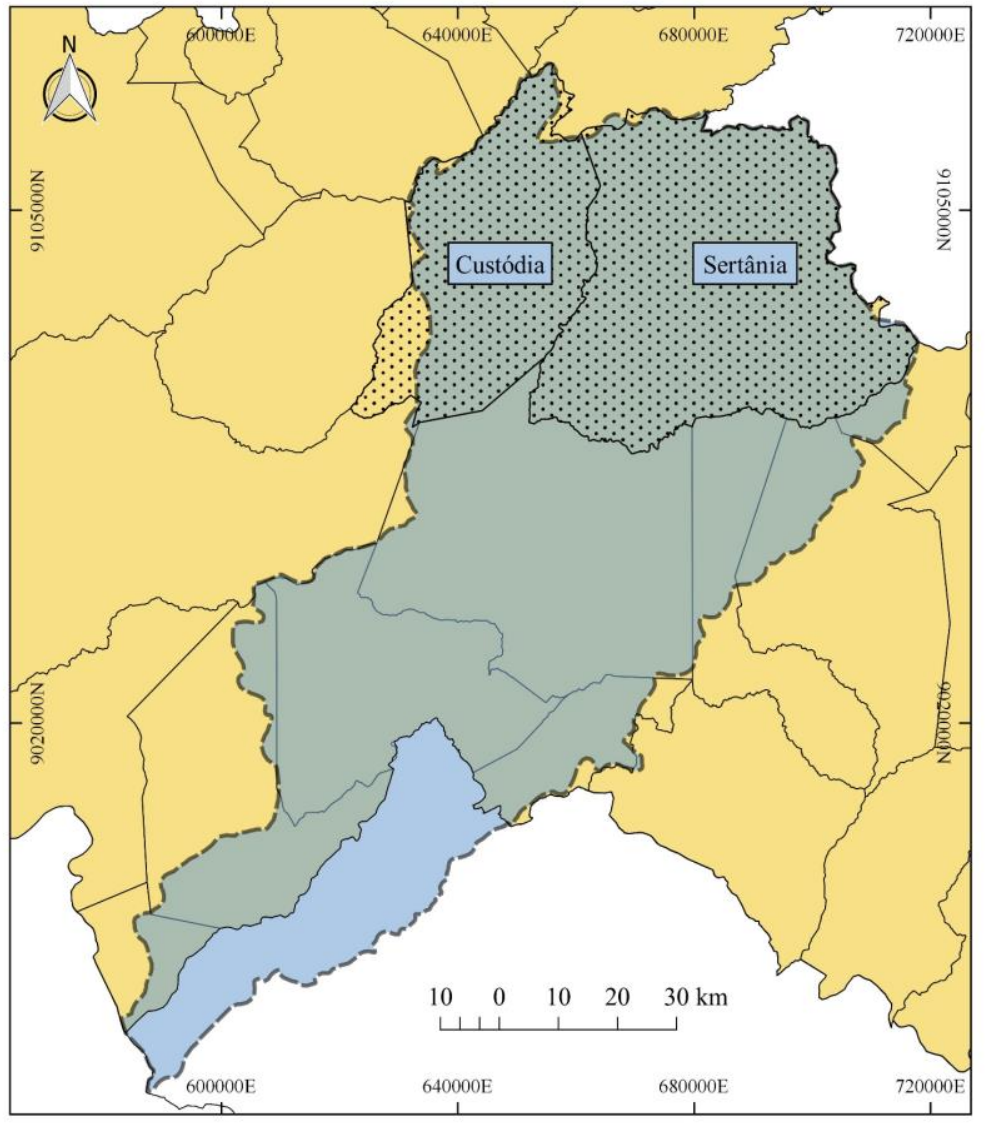

Figure 1 - Location of the study area.

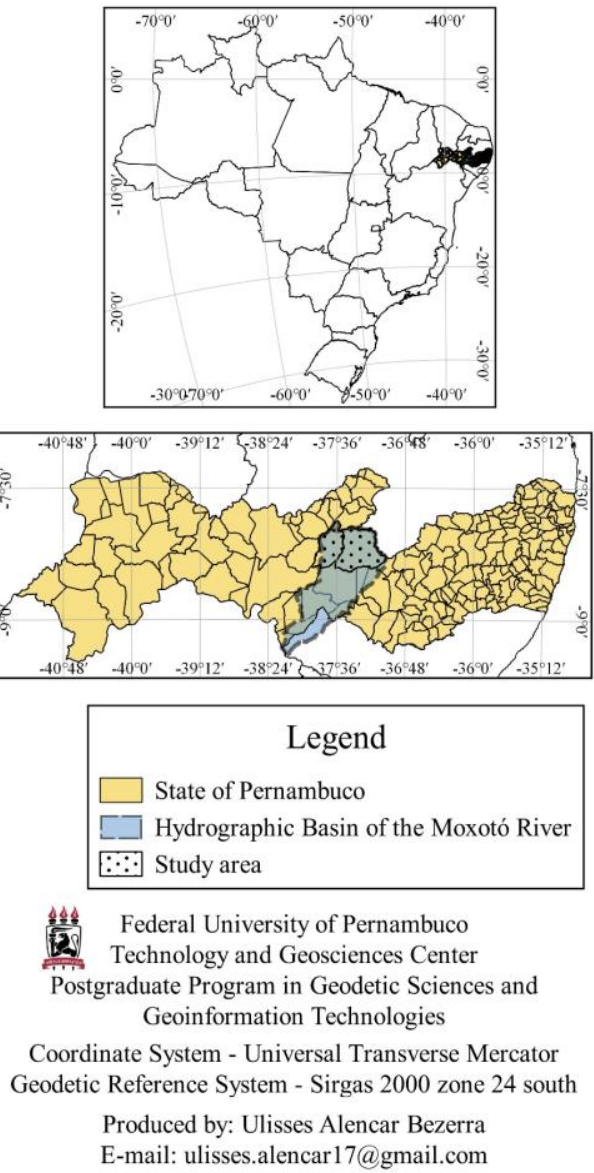

E-mail: ulisses.alencar17@gmail.com 

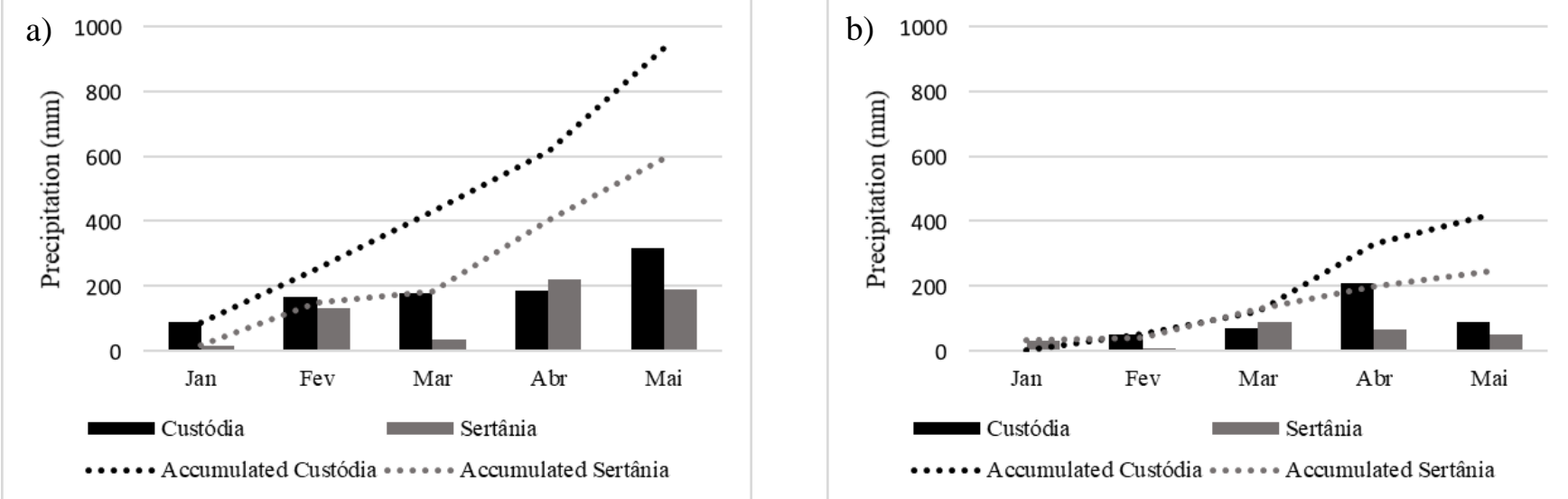

Figure 2 - Pluviometric regimen with monthly and accumulated values in the study area. a) Precipitation in 2009, b) Precipitation in 2017. Source: APAC (2017).

\subsection{Transposition of the waters of the São Francisco} River

The São Francisco River has great importance for the Northeast region, and specially for the Semiarid. It is currently responsible for the water service of 111 municipal offices located near its banks. The river is considered the main solution for the water supply of semi-arid and Agreste of Pernambuco, semi-arid of Alagoas and Sergipe and North semi-arid Norte of the state of Bahia (ANA, 2006).

According to the Ministry of National Integration (MIN), responsible for the project of transposition of the waters of the São Francisco River in the Northeast, it consists of two main systems: The Northern Axis and the Eastern Axis (Figure 3). In the East Axis with $217 \mathrm{~km}, 96.9 \%$ of the work is ready, and it will serve 4.5 million people in 168 municipalities of Pernambuco and Paraíba. In the North Axis with $260 \mathrm{~km}$, with $94.5 \%$ of the work is done, but the final stretch still depends on bidding. The axis will serve to 222 cities and 7.5 million people.

According to Ministério da Integração Nacional (2000), the objectives contained in the Transposition Plan - General Report are:

1. Increase the supply of water, in order to allow a significant increase of its multiple uses in the region;

2. Contribute to the indispensable increase in the level of guarantee required for water supply in the Northeast; and

3. Create a major strategic axis of socioeconomic and geopolitical development for the north-east hyperborean.

All systems consist of several channels, aqueducts, tunnels, reservoirs and lift stations.

The Northern Axis will take the transposed waters to the semi-arid of the states of Pernambuco, Ceará, Paraíba and Rio Grande do Norte. The East Axis will bring benefits to the semi-arid and Agreste of the states of Paraíba and Pernambuco, according to information from the Ministry of National Integration. 


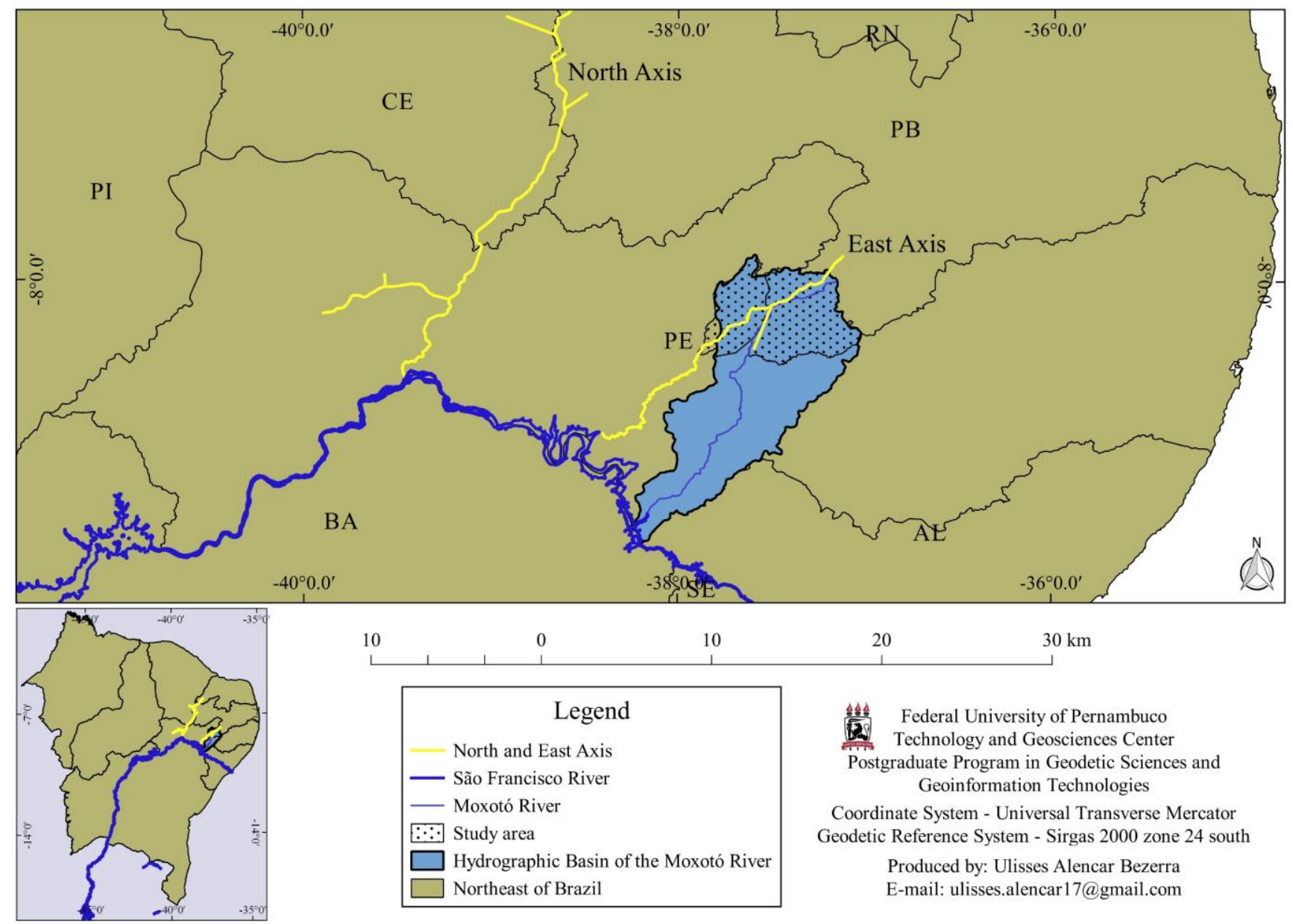

Figure 3 - Location of the Transposition Axes of the São Francisco River.

2.3 Digital image processing for NDVI and SAVI indexes

In this work, images from the Land Remote Sensing Satellite (Landsat 5), Thematic Mapper (TM) satellite, and February 4, 2017, from the Land Remote Sensing Satellite (Landsat 8) Operational Land Imager (OLI), both with 30-meter spatial resolution, purchased free of charge from the USGS (United States Geological Survey) Earth Explorer portal. For the image processing, determination of vegetation indexes and georeferenced charts, the free access software QGIS version 2.14.13 was used in this paper.

\subsubsection{TM - Landsat 5}

For the processing of NDVI and SAVI in the TM sensor of Landsat 5, spectral radiance and reflectance of bands 3 and 4 were used. The first step to obtain the NDVI and later the SAVI was the radiometric calibration proposed by Markham and Baker (1987), given by Equation 1:

$\mathrm{L}_{\lambda \mathrm{i}}=\mathrm{a}_{\mathrm{i}}+\frac{\mathrm{b}_{i}-\mathrm{a}_{\mathrm{i}}}{255} \mathrm{ND}$

Where: $\mathrm{L}_{\lambda_{\mathrm{i}}}=$ spectral radiance of each band $\left(\mathrm{W} \cdot \mathrm{m}^{-2} \mathrm{sr}^{-1}\right.$ .$\left.\mu \mathrm{m}^{-1}\right)$. "a" and "b" = minimum and maximum spectral radiance. $\mathrm{ND}=$ digital number (value between 0 and 255). $i=$ each band of TM Landsat 5 . with the values of "a" (since 1994) and "b" (after 02/04/2007) defined in the Landsat TM band descriptions Table 1, with the wavelength ranges, calibration coefficients (minimum radiance - maximum radiance - b) and spectral irradiances in the top of the atmosphere (TOA). 
Table 1 - Wavelength data $(\mu \mathrm{m})$, calibration coefficients $\left(\mathrm{Wm}^{-2} \cdot \mathrm{sr}^{-1} \cdot \mu \mathrm{m}^{-1}\right)$ and spectral irradiance at the Top of the Atmosphere $-\mathrm{k} \lambda_{\mathrm{i}}\left(\mathrm{Wm}^{-2} \cdot \mathrm{sr}^{-1} \cdot \mu \mathrm{m}^{-1}\right)$

\begin{tabular}{lcc}
\hline Bands & 3 (red) & 4 (IV near) \\
\hline Wavelength $(\mu \mathrm{m})$ & $0.626-0.693$ & $0.776-0.904$ \\
Calibration Coefficients & $\mathrm{a}=-1.17$ & $\mathrm{a}=-1.51$ \\
$\left(\mathrm{Wm}^{-2} \cdot \mathrm{sr}^{-1} \cdot \mu \mathrm{m}^{-1}\right)$ & $\mathrm{b}=264$ & $\mathrm{~b}=221$ \\
$\mathrm{k} \lambda_{\mathrm{i}}\left(\mathrm{Wm}^{-2} \cdot \mathrm{sr}^{-1} \cdot \mu \mathrm{m}^{-1}\right)$ & 1536 & 1031
\end{tabular}

Source: Adapted from Chander et al. (2009).

Monochromatic spectral reflectance of each band $\left(\rho \lambda_{\mathrm{i}}\right)$, which is given as a function of spectral radiance $\left(\mathrm{L} \lambda_{\mathrm{i}}\right)$, spectral solar irradiance of each band at the top of the atmosphere $\left(\mathrm{k} \lambda_{\mathrm{i}}\right)$, zenith angle $(\mathrm{Z}), \mathrm{E}$ is the angle of elevation of the Sun in the image metadata, and distance Earth-sun (dr) in given day of the year (DSA), according to the equations obtained by Allen et al. (2007):

$$
\begin{aligned}
& \rho \lambda \mathrm{i}=\frac{\left(\pi * L_{\lambda \mathrm{i}}\right)}{\mathrm{k}_{\lambda \mathrm{i}} * \cos Z * d r} \\
& \cos \mathrm{Z}=\cos \left(\frac{\pi}{2}-\mathrm{E}\right) \\
& \mathrm{dr}=1+0,033 \cos \left(\frac{\mathrm{DSA} * 2 * \pi}{365}\right)
\end{aligned}
$$

\subsubsection{OLI - Landsat 8}

For the processing of the NDVI and SAVI with radiometric data of the Landsat 8 OLI sensor, the radiometric calibration was performed, which consists of the conversion of the Digital Number (DN) of each pixel of the image into monochromatic spectral radiance (Equation 5).

$\mathrm{L}_{\lambda \mathrm{i}}=\mathrm{M}_{\mathrm{Li}} * \mathrm{Q}_{c a l}+\mathrm{A}_{L}$

Where: $L \lambda_{\mathrm{i}}$ is spectral radiance of each band $\left(\mathrm{W} . \mathrm{m}^{-2} \mathrm{sr}\right.$ $\left.{ }^{1} . \mu \mathrm{m}^{-1}\right) . \mathrm{M}_{\mathrm{Li}}$ is the multiplicative factor of each band, found in the file metadata (RADIANCE_MULT_BAND_i). $A_{L}$ is the addition coefficient found in the file metadata (RADIANCE_ADD_BAND_i). i refers to the band number. $\mathrm{Q}_{\text {cal }}$ are the digital numbers (DN) corresponding to each image band (USGS, 2016).

The monochromatic reflectance was calculated with the bands corresponding to the OLI sensor, were converted to planetary reflectance from the reflectance reshaping coefficient reported in the image metadata file (MTL file), using Equation 6. $\rho \lambda_{\mathrm{i}}^{\prime}=\mathrm{M}_{\mathrm{pi}} * \mathrm{Q}_{c a l}+\mathrm{A}_{p}$

Where: $\rho \lambda_{i}^{\prime}$ is the planetary reflectance without the correction of the sun angle. $\mathrm{M}_{\mathrm{pi}}$ is the multiplicative factor of each band, found in the file metadata (REFLECTANCE_MULT_BAND_i). $\quad A_{p}$ is the addition coefficient found in the file metadata (REFLECTANCE_ADD_BAND_i). i refers to the band number. Qcal are the digital numbers (ND) corresponding to each band of the image. However, it is necessary to correct the reflectance according to the zenith angle using Equation 7, (USGS, 2016; Ruhoff et al., 2015, Silva et al., 2016).

$\rho \lambda_{\mathrm{i}}=\frac{\rho \lambda_{\mathrm{i}}^{\prime}}{\operatorname{Sen}\left(\theta_{S E}\right) * \frac{1}{d^{2}}}$

Where: $\rho \lambda_{i}$ is the planetary reflectance with the correction of the zenith angle; $\theta_{S E}$ is the solar elevation; $d$ is Earth-Sun distance; present in the metadata file.

After the reflectance correction, the NDVI vegetation index and the SAVI using Equations 8 and 9 , respectively, were estimated using the near infrared ( $\rho i v)$ and red ( $\rho v)$ bands, bands 4 and 3, of the TM sensor Landsat- 5 , and 5 and 4 of the Landsat- 8 OLI sensor.

\subsection{Normalized Difference Vegetation Index (NDVI)}

NDVI acts as a sensitive indicator of the amount and condition of green vegetation. Their values range from -1 to +1 . For surfaces with some vegetation NDVI ranges from 0 and 1 ; already for water and clouds the NDVI is usually smaller than zero (Oliveira and Galvíncio, 2009).

The NDVI is obtained by the ratio of the difference of the reflectivities of the near infrared $\left(\rho_{\mathrm{iv}}\right)$ and red $\left(\rho_{\mathrm{v}}\right)$, and the sum of them.

NDVI $=\frac{\left(\rho_{\mathrm{iv}}-\rho_{\mathrm{v}}\right)}{\left(\rho_{\mathrm{iv}}+\rho_{\mathrm{v}}\right)}$

\subsection{Soil Adjusted Vegetation Index (SAVI)}

Soil characteristics have a considerable influence on the radiation spectrum from sparse vegetation canopy and, consequently, on the calculation of vegetation indices (Huete, 1988). Thus, in numerous studies, soil gloss (mainly on substrates of dark soils) has shown an increase in the value of vegetation indices such as NDVI. 
Huete et al. (1985) found that the sensitivity of vegetation indices to soil material is higher in canopies with average vegetation cover levels $(50 \%$ green cover). Therefore, an "L" constant is introduced in the SAVI, which has the function of minimizing the effect of the soil on the final index result. This constant was estimated from Huete (1988) and introduced in the experimental measurements of the calculated reflectance for the near infrared and red bands in two crops and pasture, with optimal values: $L=1$ (for low vegetation densities); $\mathrm{L}=0.5$ (for average vegetation densities); $\mathrm{L}=0.25$ (for high vegetation densities).

In general, the factor $\mathrm{L}=0.5$ offers a spectral index higher than NDVI for a wide range of vegetation conditions, but its limitation is the need to be analyzed for different biomes and agricultural situations (Huete, 1988). This index is calculated by Equation 9.

SAVI $=\frac{(1+L) *\left(\rho_{\mathrm{iv}}-\rho_{\mathrm{v}}\right)}{\left(\rho_{\mathrm{iv}}+\rho_{\mathrm{v}}+L\right)}$

\section{Results and Discussion}

For the classification of the vegetation indexes of the present study, the methodology proposed by Chagas et al. (2008), which relates the reflectance values of the biophysical index to the vegetation density (Table 2).

The classes used to interpret vegetation indices were the same for NDVI and SAVI. In Figure 4, it is possible to observe the calculated NDVI in the upper region of the Moxotó river basin for the years 2009 and 2017.

According to Figueirêdo et al. (2013), the negative values of NDVI and SAVI represent water bodies and / or clouds. Oliveira et al. (2013), argued that NDVI classes with lower values $(0.00-0.20)$, located in urban areas, constitute stressed vegetation or an area degraded by anthropic action, due to water scarcity, which has the consequence of exposure with deforestation and environmental degradation. According to Huete and Tucker (1991), the NDVI for the exposed soils are generally in the range of 0.05 to 0.30 , however, due to the optical properties of the soil, a strict range of values of NDVI for soils with little or no vegetation.

Table 2 - Classes of vegetation and land use and their respective biophysical index-image reflectance values.

\begin{tabular}{cc}
\hline $\begin{array}{c}\text { Classes of vegetation } \\
\text { and land use }\end{array}$ & Reflectance values \\
\hline Dense vegetation & $>0.35$ \\
Transition vegetation & $0.30 \mathrm{a} 0.35$ \\
Sparce Vegetation & $0.25 \mathrm{a} 0.30$ \\
Weak vegetation & $0.20 \mathrm{a} 0.25$ \\
Exposed soil & $0,00 \mathrm{a} 0.20$ \\
Bodies of Water & $<0,00$ \\
\hline
\end{tabular}

Source: Adapted from Chagas et al. (2008)

From the analyzes of the georeferenced charts of the NDVI (Figure 4) and Table 3, in which it expresses the percentage of each class, it was verified that in 2009 the types of water bodies $(0.224 \%)$ and dense vegetation $(14.755 \%)$, were predominant in the study area, and that in 2017 the studied region presented less soil exposure, a reduction of $17.02 \%$, and a larger contribution of sparse vegetation, representing an increase of $26.20 \%$ for the same period of the year. These scenarios may be related to the pluviometric contribution in the year 2009, which was higher than the year 2017 (Figure 2). As observed in Figure 4, the 2009 NDVI presents several water bodies, in which they were not identified in the NDVI of 2017. 


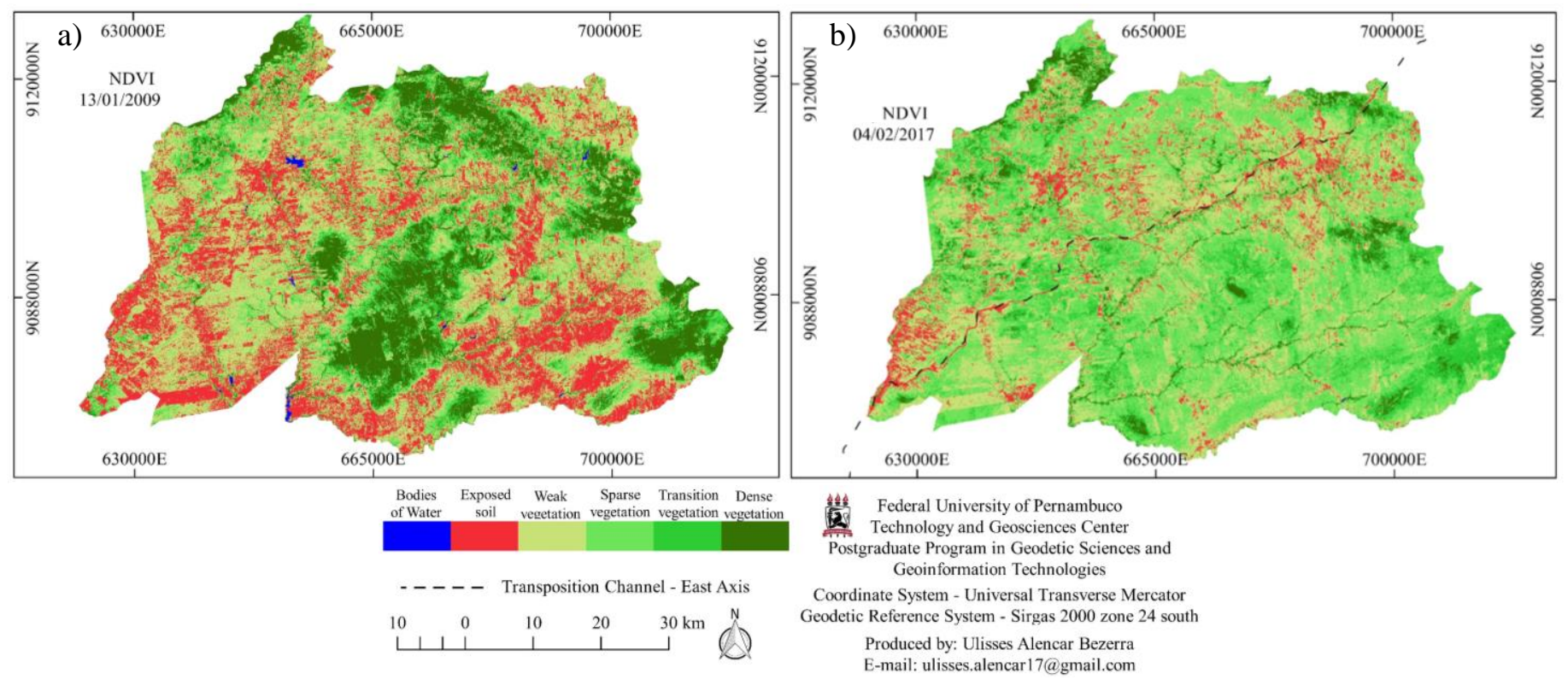

Figure 4 - Results for NDVI for the upper region of the Moxotó River Basin. (a) Day January 13, 2009. (b) Day February 4, 2017.

Table 3 - Percentage of NDVI classes analyzed

\begin{tabular}{lrrrr}
\hline & \multicolumn{2}{c}{ NDVI 2009 } & \multicolumn{2}{c}{ NDVI 2017 } \\
\hline \multicolumn{1}{c}{ CLASS } & Area (ha) & Area (\%) & Area (ha) & Area (\%) \\
\hline Bodies of Water & 854.82 & 0.224 & 14.13 & 0.004 \\
Exposed soil & 94573.82 & 24.733 & 29488.05 & 7.712 \\
Weak vegetation & 136442.90 & 35.682 & 122618.88 & 32.067 \\
Sparse vegetation & 59585.51 & 15.583 & 159787.80 & 41.787 \\
Transition vegetation & 34505.66 & 9.024 & 52864.38 & 13.825 \\
Dense vegetation & 56422.73 & 14.755 & 17612.19 & 4.606 \\
TOTAL & 382385.43 & 100 & 382385.43 & 100 \\
\hline
\end{tabular}

The values for dense, sparse and sparse vegetation for NDVI corroborate others obtained in existing studies, in other regions such as Chagas et al. (2008), Oliveira and Galvíncio (2009), Oliveira et al. (2013) and Brito et al. (2015).

Another interesting aspect, comparing the NDVI of the years studied, was the fact that the study area was modified in eight years, highlighting the São Francisco River Transposition channel (Figure 4), in the NDVI of 2017, absent in the index of It is worth noting the absence or the small presence of vegetation along the edges of the canal, which should be composed of ciliary forest, which according to Carrenho et al. (2001), the ciliary forests are fundamental in the conservation of rivers, in the quality and quantity of water in the springs, cooperating with the maintenance cycle of local biodiversity.
Table 4 presents some statistical parameters for the NDVI presented in this study, considering values smaller than 0 (zero) going to greater than 0.78 . These values show features on the terrestrial surface with photosynthetically active vegetation relating the biomass and the chlorophyll content present. This result agrees with Oliveira et al. (2013) when they detected NDVI higher than 0.80 in the catchment area of the basin Tapacurá river.

In SAVI, in which it is one of the indices considered hybrids, to use the ratio of bands with adjustment parameters to minimize the effect of the presence of soil in the middle of the vegetation. The adjustment parameters may or may not consider the soil line coefficients, but always express the intention of minimizing the soil bottom effect (SANTIAGO et al., 2009). 
Table 4 - Statistical values of NDVI analyzed

\begin{tabular}{ccccc}
\hline Image & Min & Mean & Max & Stand. Dev. \\
\hline Jan 09 - NDVI & -0.582 & 0.256 & 0.774 & 0.007 \\
Fev 17 - NDVI & -0.455 & 0.264 & 0.785 & 0.003 \\
\hline
\end{tabular}

In Figure 5, it is possible to observe the SAVI calculated in the upper region of the hydrographic basin of the Moxotó river for the years 2009 and 2017.

It is observed that the negative values of SAVI are representing the water (blue color), present mainly in the 2009 SAVI.
In Figure 5, the lowest values of the SAVI index are areas with exposed soil or sparse vegetation, with emphasis on the São Francisco River Transposition channel in 2017, and the highest SAVI values are areas with dense vegetation (green dark).

When analyzing the georeferenced charts of the SAVI (Figure 5) and Table 5, with the percentage values of each class, it is verified that the results express similarities in relation to the results obtained with the NDVI values (Figure 4). However, the SAVI highlighted the influence of the exposed soil, mainly at the beginning of the resumption of vegetation development in the studied areas.

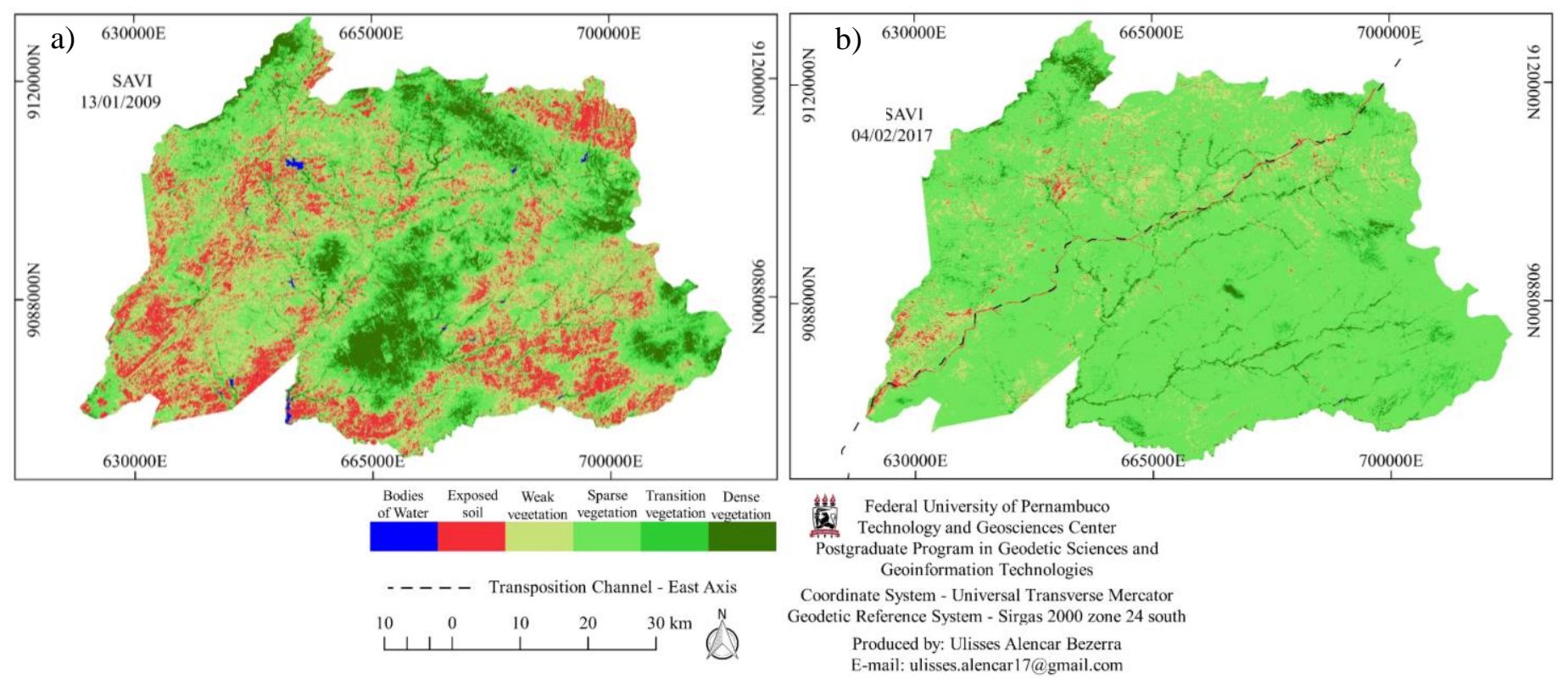

Figure 5 - SAVI result for upper region of the Moxotó River Basin. (a) Day January 13, 2009. (b) Day February 4, 2017.

It is observed that the sparse vegetation class obtained a high percentage, in the year 2017 compared to the year of 2009. In analyzing Tables 2 and 4, it is verified how much the SAVI, has the utility of reducing the effects of the soil when compared to the NDVI, since the percentage of the Solo class exposed was reduced from $24.73 \%$ to $17.18 \%$ in 2009 and $7.71 \%$ to $1.536 \%$ in 2017 .
The values for vegetation of the SAVI corroborate others obtained in existing studies, in other regions such as Novas et al. (2009), Oliveira and Galvíncio (2009), and Cruz et al. (2011).

Table 6 presents some statistical parameters, for the SAVI presented in this study, we consider values less than 0 (zero) going to greater than 0.63. 
Table 5 - Percentage of SAVI classes analyzed

\begin{tabular}{lrrrr}
\hline \multicolumn{1}{c}{ CLASS } & \multicolumn{2}{c}{ SAVI 2009 } & \multicolumn{2}{c}{ SAVI 2017 } \\
\hline Bodies of Water & Area (ha) & Area (\%) & \multicolumn{1}{c}{ Area (ha) } & Area (\%) \\
Exposed soil & 854.82 & 0.224 & 14.13 & 0.004 \\
Weak vegetation & 65701.28 & 17.182 & 5874.39 & 1.536 \\
Sparse vegetation & 115537.9 & 30.215 & 38372.85 & 10.035 \\
Transition vegetation & 133709.70 & 34.967 & 311336.28 & 81.419 \\
Dense vegetation & 31242.26 & 8.170 & 18459.90 & 4.828 \\
TOTAL & 35339.51 & 9.242 & 8327.88 & 2.178 \\
& 382385.43 & 100 & 382385.43 & 100 \\
\hline
\end{tabular}

Table 6 - Statistical values of SAVI analyzed

\begin{tabular}{ccccc}
\hline Image & Min & Mean & Max & Stand. Dev. \\
\hline Jan 09-SAVI & -0.526 & 0.147 & 0.639 & 0.002 \\
Fev 17 - SAVI & -0.089 & 0.155 & 0.540 & 0.001 \\
\hline
\end{tabular}

Comparing the statistical values of NDVI to SAVI, we can observe that the second one has as a precept to minimize the effect of soil on the result of the index. This result is according to Huete (1988), where NDVI has problems in identifying the vegetation cover in these cases in which the vegetation is sparse, so the SAVI model has the purpose of having a global application, that is, to deal with the effects of the variation of density between vegetation and soil. Therefore, the effect of the soil on the result of the index is smoothed in relation to the NDVI.

\section{Conclusions}

The analysis of the vegetation indices applied in the upper region of the Moxotó river basin showed differences between the vegetation cover determined by the SAVI and NDVI, before and after the Transposition of the São Francisco River.

The Normalized Difference Vegetation Index (NDVI) and the Soil Adjusted Vegetation Index (SAVI) presented similar spatial dynamics in the years studied, showing the expansion of urban areas, as well as the characterization of the São Francisco River Transposition channel and the temporal dynamics of the terrestrial surface, in the upper region of the Moxotó river basin - PE, using orbital images TM Landsat 5, and OLI Landsat 8.

NDVI presented mean values for 2009 and 2017 of 0.256 and 0.264 , showing a vegetative cover growth and photosynthetic activity. SAVI, meanwhile, had averages of 0.147 and 0.155 for the years of 2009 and 2017, highlighting its correction to soil effects.

Using the NDVI and SAVI indexes, it was possible to identify with greater precision, not only the areas of vegetation cover, but also the changes in the temporal behavior of the environment, as well as the anthropic interventions such as the São Francisco river transposition channel.

\section{Acknowledgments}

The authors would like to thank the Conselho Nacional de Desenvolvimento Científico e Tecnológico (CNPq) and the Coordenação de Aperfeiçoamento de Pessoal de Nível Superior (CAPES) for the incentive to research and grant scholarships, to the United States Geological Survey (USGS) and the Agência Pernambucana de Águas e Clima (APAC), to the images and database respectively used in the work.

\section{References}

ANA. Agência Nacional das Águas, 2006. Atlas Nordeste - Abastecimento Urbano de Água. Ministério do Meio Ambiente; Superintendência de Planejamento de Recursos Hídricos - SPR, Brasília.

Allen, R.G., Tasumi, M. Trezza, R., 2007. Satellitebased energy balance for mapping evapotranspiration with internalized calibration (METRIC) - Model. Journal of Irrigation and Drainage Engineering 133, 380-394.

Alves, T.L.B., Azevedo, P.V., Santos, C.A.C., Santos, F.A.C., 2014. Comportamento Sazonal do Albedo e dos Índices de Vegetação na Bacia Hidrográfica do 
Alto Curso do Rio Paraíba. Revista Brasileira de Geografia Física 7, 1015-1027.

Antunes, R.L.S., 2014. Variação espaço-temporal de NDVI em área de aproveitamento hidroelétrico UHE santo Antônio, Porto Velho (RO). Dissertação (Mestrado). Recife, UFPE.

APAC. Agência Pernambucana de Águas e Climas, 2017. Sistema de Informação Geográfica. Disponível: http://www.apac.pe.gov.br/sighpe/. Acesso: 4 maio 2017.

Brito, F.B., 2013. Conflitos pelo acesso e uso da água: integração do rio São Francisco com a Paraíba (Eixo Leste). Tese (Doutorado). Porto Alegre, UFRGS.

Brito, D.S., Pinheiro, M.A., Grangeiro, C.M.M., Silva, J.M.O., 2015. Análise da Aplicação do Índice de Vegetação por Diferença Normalizada (NDVI) Na Microbacia o Rio Salamanca, Barbalha-Ceará. Workshop de Mudanças Climáticas e Recursos Hídricos do Estado de Pernambuco, Recife.

Carrenho, R., Trufem, S.F.B., Bononi, V.L.R., 2001. Fungos micorrízicos arbusculares em rizosferas de três espécies de fitobiontes instaladas em área de mata ciliar revegetada. Acta Botanica Brasílica 15, 115-124.

Chagas, M.G.S.das, Galvíncio, J.D., Pimentel, R.M.M., 2008. Avaliação da dinâmica espectral da vegetação de caatinga em Arcoverde, Pernambuco. Revista de Geografia 25 45-60.

Chander. G., Markham, B.L., Helder, D.L., 2009. Summary of current radiometric calibration coefficients for Landsat MSS, TM, ETM+, and EO1 ALI sensors. Remote Sensing of Environment 113, 893-903.

Constantini, M.L., Zaccarelli, N.; Mandrone, S., Rossi, D., Calizza, E., Rossi, L., 2012. NDVI spatial pattern and the potential fragility of mixed forested areas in volcanic lake watersheds. Forest Ecology and Management 285, 133-141.

Cruz, M.A.S., Souza, A.M.B., Jesus, J.S., 2011. Avaliação da cobertura vegetal por meio dos Índices de Vegetação SR, NDVI, SAVI e EVI na bacia do rio Japaratuba-Mirim em Sergipe. Simpósio Brasileiro de Sensoriamento Remoto, Curitiba.

Figueirêdo, A.C., Montenegro, A.A.A., Santos, E.S., Guerra, S.M.S., Gusmão, A.C.V.L., 2013. Determinação de Índices de Vegetação para a análise da cobertura vegetal em bacia hidrográfica do Agreste pernambucano. Simpósio Brasileiro de Sensoriamento Remoto, Foz do Iguaçu.

Gheyi, H.R., Paz, V.P.S., 2012. Recursos Hídricos em Regiões Semiáridas. Campina Grande.
Gomes, V.P., Galvíncio, J.D., Ferreira, P.S., Silva, J.F., Ferreira, H.S., 2016. Hyperspectral analysis in areas of Caatinga degraded in the municipality of Sertânia - PE. Journal of Hyperspectral Remote Sensing 6, 262-269

Huete, A.R., Jackson, R.D., Post, D.F., 1985. Spectral response of a plant canopy with different soil background. Remote Sensing of Environment 17, $37-53$.

Huete, A.R., 1988. A soil-adjusted vegetation index (SAVI). Remote Sensing of Environment 25, 53-70.

Huete, A.R., Tucker, C.J., 1991. Investigation of soil influence in AVHRR red and near infared vegetation index imagery. International Journal of Remote Sensing 12, 1223-1242.

Lima, G.C., Silva, M.L.N., Curi, N., Silva, M.A., Oliveira, A.H., Avanzi, J.C., Ummus, M.E., 2013. Avaliação da cobertura vegetal pelo índice de vegetação por diferença normalizada (IVDN). Ambi-Agua 8, 204-214.

Lopes, A.S., Silva, H.P., Araujo, I.R., Alencar, B.P.B., Melo, A.L., 2010. Utilização de imagens de satélites e dados meteorológicos visando o monitoramento de mudanças climáticas. Simpósio Brasileiro de Ciências Geodésicas e Tecnologias da Geoinformação, Recife.

Markham, B.L., Barker, L.L., 1987. Thematic mapper bandpass solar exoatmospherical irradiances. International Journal of Remote Sensing 8, 517523.

Marcussi, A.B., Bueno, C.R.P., Miqueloni, D.P., Arraes, C.L., 2010 Utilização de índices de vegetação para os sistemas de informação geográfica. Caminhos de Geografia - Revista online $11,41-53$.

Melo, C.R., 2011. Análise do eixo leste da transposição do rio São Francisco face aos cenários de uso previstos. Dissertação (Mestrado). Recife, UFPE.

Ministério da Integração Nacional, 2000. Projeto de Transposição das águas do rio São Francisco, Relatório Geral, TOMO I, TOMO II; Análise Prospectiva da Irrigação, TOMO 2b. VBA Consultores.

Novas, M.F.B., Cruz, P.P.N., Silva, R., Pace, T.T., 2008. Análise da Variação dos Índices de Vegetação Estimados por Sensoriamento Remoto em dois Períodos ao Sul da Bacia do Rio Traipu-AL. Simpósio Brasileiro de Ciências Geodésicas e Tecnologias da Geoinformação, Recife.

Oliveira, L.M.M.; Montenegro, S.M.G.L., Silva, B.B., Moura, A.E.S.S.; Gusmão, A.C.V.E.L., Salgueiro, 
J.H.P.B., 2013. Índices de vegetação por sensoriamento remoto na bacia hidrográfica do rio Tapacurá - PE. Simpósio Brasileiro de Recursos Hídricos, Bento Gonçalves.

Oliveira, T.H, Galvíncio, J.C., 2009. Caracterização Ambiental da Bacia Hidrográfica do rio Moxotó PE Usando Sensoriamento Remoto Termal. Revista Brasileira de Geografia Física 1, 30-49.

Ponzoni, F.J., Shimabukuro, Y. E., Kuplich, T.M., 2012. Sensoriamento Remoto da Vegetação. 2 ed. Oficina de Textos, São Paulo.

Rouse, J.W., Haas, R.H., Schell, J.A., Deering, D.W., 1973. Monitoring the vernal advancement and retrogradation (green wave effect) of natural vegetation. Prog. Rep. RSC 1978-1. Remote Sensing Cent. Texas A\&M University, College Station.

Ruhoff, A.L., Silva, B.B., Rocha, H.R., 2015. Determinação da irradiância solar no topo da atmosfera para cálculo do albedo e balanço de energia a partir de imagens LANDSAT 8 OLI. I Simpósio Brasileiro de Sensoriamento Remoto, João Pessoa.

Santiago, M.M., Silva, H.A., Galvíncio, J.C., Oliveira. T.H., 2009. Análise da Cobertura Vegetal Através dos Índices de Vegetação (NDVI, SAVI e IAF) no entorno da barragem do Botafogo-PE Simpósio Brasileiro de Sensoriamento Remoto, Natal.

Silva, B.B., Braga, A.C., Oliveira, L.M.M., Montenegro, S.M.G.L.; Barbosa Junior, B., 2016. Procedures for calculation of the albedo with OLILandsat 8 images: Application to the Brazilian semi-arid. Revista Brasileira de Engenharia Agrícola e Ambiental 20, 3-8.

Silva, T.G.F., Moura, M.S.B., Zolnier, S., Moura, L.S.B., Carmo, J.F.A., 2014. Índices morfofisiológicos e uso de radiação solar por um cultivo de cana-de-açúcar irrigada no semiárido brasileiro. Revista Brasileira de Geografia Física 7, $764-773$.

UNESCO. Organização das Nações Unidas para a Educação, a Ciência e a Cultura, 2017. Relatório Mundial das Nações Unidas sobre Desenvolvimento dos Recursos Hídricos. Disponível: http://www.unesco.org/water/wwap. Acesso: 4 maio 2017.

USGS, 2016. Landsat 8 (L8) Data Users Handbook, 2015, LSDS-1574, version 1.0. Sioux Falls, USA: USGS EROS. Disponível: https://landsat.usgs.gov/documents/Landsat8DataUs ersHand book.pdf. Acesso: 5 maio 2017. 